\title{
ПАРЛАМЕНТСКИЕ ВЫБОРЫ В ВЕНГРИИ 2018 Г.
}

Аннотация. Венгерские парламентские выборы 2018 года в четвертый раз за новейшую историю страны принесли победу партии ФИДЕС. Одновременно нынешняя избирательная кампания завершилась небывальмм провалом сочиал-либеральной оппозиции, пользующейся активной поддержкой Брюсселя. Сюрпризом выборов стала также отставка создателя и бессменного лидера праворадикальной партии Йоббик, несмотря на лучший за всю историю результат его партии: впервые она обошла своих политических соперников и, одновременно, соратников по оппозиции - венгерских социалистов. Однако, несмотря на очередную убедительную победу, новому кабинету ФИДЕС предстоит непростое правление на фоне попыток объединения оппозиции и противостояния с официальным Брюсселем.

Ключевые слова: парламентские выборы, Венгрия, партийная борьба, ФИДЕС, оппозиция.

Восьмые по счету демократические выборы в Венгрии в четвертый раз за новейшую историю страны принесли победу партии ФИДЕС, в том числе, третий раз подряд. В 1998 году в возрасте 35 лет бессменный лидер партии Виктор Орбан стал вторым самым молодым премьер-министром страны ${ }^{1}$, рекорд по суммарной длительности пребывания во главе кабинета министров $^{2}$ он побил уже в 2016 году. Если посмотреть на региональный и европейский масштаб, то и здесь Виктор Орбан удерживает первые позиции. Он стал известен и управлял страной тогда, когда никто еще даже не слышал об Ангеле Меркель, не говоря уже о других президентах и премьерах современной Европы, от которых ему так «достается» сегодня в Брюсселе. Однако канцлер Германии все еще на год дольше по бессменному пребыванию на посту премьер-министра страны.

\section{Какие силы участвовали в выборах?}

В избирательном бюллетене было 23 партии и объединения. Среди них старожилами венгерской политики являются: сам ФИДЕС (с 2000-ых гг. выступающий в коалиции с Христианско-демократической народной партией), Венгерская социалистическая партия (ВСП) и

(С Шишелина Л.Н. - доктор исторических наук, заведующая Отделом исследований Центральной и Восточной Европь ИЕ РАН. Адрес: 125009, Москва, ул. Моховая, 11-3. E-таіl: l.shishelina@gmail.com

Статья подготовлена при финансовой поддержке РФФИ в рамках проекта № 17-07-00016 “Россия и Центральная Европа: проблемы и перспективы взаимоотношений в условиях мирового политического кризиса".

DOI: http://dx.doi.org/10.15211/vestnikieran2201811

${ }_{1}^{1}$ После Андраша Хегедюша, который в 1955 году возглавил кабинет министров в возрасте 33 года.

${ }^{2}$ На сегодня это 12 лет. 
другой наследник кадаровской ВСРП - Венгерская партия рабочих (чей результат никогда не достигал и $1 \%$ ). Для большинства же партий это вторые или третьи выборы.

Всплеск партийного строительства наблюдался в Венгрии после уличных протестов 2006 года, когда родился знаменитый Йоббик - Партия за лучшую Венгрию, а также наследники распавшегося тогда же либерального Союза свободных демократов. Из совсем новых партий - это партия Двухвостой собаки, созданная мастерами уличного плаката и графити, кредо которой - сарказм, а также несколько партийных объединений, возникших на соросовской волне антифидесовского протеста, типа Моментума.

Кредо и программа ФИДЕС остаются неизменными на протяжении последних трех кампаний. В этот раз, однако, преобладала тема защиты пространства страны от неконтролируемой волны мигрантов и навязываемых Брюсселем обязательств по квотам.

Венгерская социалистическая партия уже третьи выборы подряд не может оправиться от поражения, которое стало наследием правления плеяды сторонников Ференца Дюрчаня. С 2010 года ей в спину дышит право-радикальная Йоббик, а количество поддерживающих избирателей неуклонно снижается. Одна из главных проблем партии в том, что она не может найти лидера. Нет достаточно харизматичной и сильной волевой фигуры, хотя в партии остается много узнаваемых лиц, в том числе, из правительств «золотой поры социаллибералов». Вот и на этот раз коалицию возглавил представитель совсем маленькой новой партии Диалог - Гергей Карачонь.

Партию Йоббик к выборам 2018 года вел ее бессменный и уверенный в себе лидер Габор Вона. За прошедшие годы партия отказалась от сильно раздражавших Брюссель маршей Национальной гвардии, изменилась и ее программа. В частности, из нее исчезла задача вывода Венгрии из Европейского союза. Напротив, появилась поддержка евро. Правые радикалы по-прежнему заявляют о стратегически важном партнерстве с Россией и одновременно об учитывающем интересы Венгрии сотрудничестве с США.

Партии либерального спектра строили свою избирательную кампанию на отрицании всех предложений ФИДЕС. Обвиняя партию Орбана в антигуманной политике по отношению к мигрантам с юга, лидер Демократической коалиции Ференц Дюрчань, например, одновременно пенял правящей партии относительно «особой политики по интеграции жителей Украины во внутриполитическую жизнь Венгрии», в том числе, привлекая их к голосованию. Здесь следует отметить, что с прошлых выборов голосовать за партийные листы могут также и жители соседних стран, где венгры имеют крупные диаспоры и паспорт гражданина Венгрии.

Все либеральные партии указывают на угрозу, исходящую от российской пропаганды, и в целом, политики России, призывая «очиститься от российского влияния», которое ныне рассматривают как беспрецедентное. Такие намерения, в частности, внесла в свою программу уже упомянутая нами молодежная партия Моментум.

В остальном, программы отличались лишь размером обещаний повышения зарплат (кто 20\%, кто - 30\%), снижением налогов, стоимости услуг ЖКХ и интернета.

Однако стоит отметить важную, на наш взгляд, тенденцию - коррекция внешнеполитических приоритетов. Если при первых выборах преобладала ориентация на Запад, в про- 
межутке - примерно с рубежа 1990-2000 гг. - ориентация на Россию и Восток в качестве баланса, то теперь в программах всех партий речь идет о первостепенности региональных интересов. Большинство партий озабочено состоянием дел в пространстве от Балтики до Адриатики и Черного моря. Впервые в качестве отдельного пункта практически у всех выделяется Вишеградская группа как главный ориентир для приложения внешнеполитических усилий. У ФИДЕС также подчеркнута «особость» отношений с Польшей.

Правые и право-центричные партии педалируют проблему ограничения миграции. Либеральные же партии ратуют за движение в одном направлении и одинаковыми темпами с Европейским союзом. 28-летний новичок в политике и лидер Моментума обвиняет правительство в навязывании населению боязни перед мигрантами.

\section{День выборов - 8 апреля 2018 года}

Выборы 2018 года отличались повышенной избирательной активностью. Желавших отдать свой голос было столь много, что на двух избирательных участках Будапешта пришлось на три часа продлить время голосования. По этой причине результаты стали известны ближе к утру следующего дня.

Ныне Венгрия второй раз голосовала по чертежам В. Орбана, т.е. в соответствии с изменениями, внесенными ФИДЕС в Закон о выборах. На 199 мест в парламенте депутаты избираются по партийным спискам и единолично. 96 мест получают пропорционально итогам преодолевшие 5\% барьер депутаты по партийным спискам и 106 - от округов. Целью конституционной реформы В. Орбана было упрощение и удешевление процедуры выборов. Ныне они проводятся в один тур, ради чего был снят ранее существовавший явочный ценз, а кроме того, депутатский корпус уменьшился в два раза (ранее Парламент состоял из 386 депутатов). ФИДЕС в этот раз достаточно было набрать 51\%, чтобы сформировать кабинет министров.

В целом завершившуюся 8 апреля 2018 года избирательную кампанию можно назвать небывалым провалом оппозиции. При этом коалиция ФИДЕС/ХДНП закрепила свой результат 2010 и 2014 годов, получив конституционное большинство в Парламенте - 66,83\% или 133 мандата из 199. Лево-либеральный спектр показал худшие результаты за всю историю выборов.

Венгерская социалистическая партия почти три десятилетия являвшаяся главным соперником ФИДЕС, скатилась до результата в 10\% представительства в Парламенте, получив всего 20 мандатов. Все годы «после Дюрчаня» партия меняла лидеров, но в результате, вынуждена была пойти на выборы в коалиции с партией Диалог, уступив ей заодно и лидерство. Новые либеральные партии - Возможна другая политика и Демократическая коалиция едва преодолели избирательный барьер, получив соответственно 8 и 9 мест в Парламенте.

На этом фоне впервые праворадикальная партия Йоббик пришла к финишу избирательной борьбы второй, показав одновременно и лучший в истории партии результат - 13,1\% или 26 мандатов. Однако это не устроило лидера партии Габора Вону, который был уверен, что опередит Виктора Орбана. Вместе с проигрышем в своем одномандатном округе он воспринял результат партии как провал и на этой волне объявил о своей отставке. Что ожидает партию дальше? Скорее всего, раскол и в перспективе частичное примыкание к про- 
фидесовской коалиции, так как, несмотря на попытки совместной игры руководства Йоббик с либеральным спектром против Орбана в ходе предвыборной кампании, все же их избиратели не совмещаются по идеологии.

По одному мандату получили представители партии Вместе и Немецкой общины Венгрии, а также независимый кандидат.

После выборов, серьезная реконструкция ожидает и лево-либеральный спектр. О своей отставке, кроме Габора Воны, уже объявил лидер социалистов, сопредседатель партии Возможна другая политика, полностью покидает свои посты руководство партии Вместе.

Отвлекавшие на себя внимание последние годы абсурдистская партия Двухвостой собаки, обклеивавшая Будапешт обличительными плакатами, и молодежный Моментум, возникший на волне протестов против удорожания интернета и защиты университета Сороса, в парламент не прошли. Но если первая партия оказалась довольна результатом участия, то молодой и пока никому толком не известный (как и все руководство партии) лидер Моментума с горяча обрушился с критикой на народ.

\section{Почему Орбан?}

Многие задаются вопросом: в чем секрет Орбана и его партии, созданной в 1988 году как Альянс молодых демократов и несущей это название до сих пор, даже несмотря на то, что лидер год назад стал дедушкой?

Наверное, главное - политическое чутье, умение правильно услышать пульс общества и выбирать приоритеты. Виктор Орбан, как и многие, с кем он создавал партию - по рождению провинциал, хотя и родился в Венгерской первопрестольной - г. Секешфехервар (что переводится как Святой белый город), месте коронации первых венгерских королей. Следовательно, он представляет собой не элитарную, а самую что ни на есть срединную Венгрию и не понаслышке знает будни небольших венгерских городов. Именно в этом городе в этот раз он провел свой последний предвыборный митинг.

Политик он тоже в первом поколении. Возраст расставания со студенческой скамьей совпал у него со временем поиска нового пути страной. Это стало решающим фактором. Способствовало этому и юридическое образование. Таким образом, здесь слилось много факторов помимо личных лидерских волевых качеств: в унисон со временем, средой, запросами общества...

Четвертый срок для Орбана - это номинально. Он никогда не был серой фигурой с момента своего появления в политике в конце 1980-ых (недавно партия отметила свое 30летие). И хотя на выборах 1990 года его партия набрала всего 9\% голосов, и его не взяли в коалицию те, кого он принял в соратники сегодня, он всегда был заметен в политике, что и привело его в 1998 году на пост премьер-министра. В ходе выборов 2001 и 2006 гг. партия ФИДЕС проигрывала социал-либеральной коалиции в пределах $1 \%$. Плюс/минус. Потому лидер и его партия считались сильной оппозицией. Наконец, в 2010 г. Орбан призвал соотечественников не сидеть на диванах, ожидая чуда, а идти на выборы. Огромная явка дала ФИДЕС не только победу, но и конституционный перевес. Второй раз, после срока, омраченного постоянными тяжбами с Евросоюзом, партия не рассчитывала на повторение успеха, 
однако венгры оценили усилия лидера по защите интересов страны. В 2014 году партия во второй раз получила конституционное большинство, и в 2018 - в третий раз.

\section{Что показали прошедшие выборы?}

То, что Венгрия снова после 2000-х стоит перед проблемой формирования второго полноценного и конкретного политического спектра, которым руководит не личная неприязнь к правящим политикам, а зрелая политическая позиция.

Что влияние средств массовой информации на избирателя не столь велико, как надеются политики, скупая время в эфире и полосы в бумажных и электронных медиа. Избиратель в основном (в отличие от партий) имеет твёрдую житейскую позицию.

Что нынешняя либеральная оппозиция плохо ориентируется в реальных настроениях в своей стране. Об этом свидетельствует масса допущенных стратегических ошибок. Так оппозиция считала, что, чем больше избирателей придет на участки, тем больше шансов победить существующую власть. Они не учли, что то, что они видят в репортажах из Брюсселя о своей стране, не совпадает с тем, как чувствует себя реальный избиратель. То, что удалось Орбану в 2010 году, не работает в других случаях.

Другое - оппозиция рассчитывала победить в одномандатных округах. Все антиправительственные партии стали участниками кампании по снятию кандидатов в пользу, на их взгляд, более перспективных в противостоянии ФИДЕС. Однако на этот раз правящая партия уверенно победила в 91 из 106 одномандатных округов. Уступила она только в Будапеште, где на ее долю пришлось только 6 из 18 мандатов и еще в нескольких небольших округах. [Valasztás:2018]

Что зарубежная диаспора, получившая от правящей партии вместе с паспортом гражданина Венгрии и право голоса, неизменно поддерживает ФИДЕС, являясь его немалочисленной опорой.

Наконец, то, что позитивная программа действий и зримый результат действуют на избирателя эффективнее, нежели обещания все разрушить - тем более, когда исходят от малоизвестных начинающих политиков. Орбану за годы правления удалось укрепиться на кампании налогообложения банков и мультинациональных кампаний, выдворении из страны МВФ (расплатившись с долгами предыдущего правительства социалистов), удешевлении услуг ЖКХ, борьбе с навязанными Брюсселем квотами по приему мигрантов и других шагах, спасших страну от экономического кризиса. Население хочет безопасности и новых рабочих мест с достойной зарплатой. Новому кабинету предстоит еще сосредоточиться на проблемах здравоохранения и образования. А в целом - результаты выборов подкрепили мандат Орбана в его полемике с Брюсселем.

Как и другие партии региона, ФИДЕС провозглашает в первую очередь ориентацию на свой регион, подчеркивая важность хороших отношений с соседями и, в условиях обострившегося противостояния с Брюсселем, особенно с Польшей. Никто пока что не заменил для страны важность членства в ЕС и опоры на структуры НАТО в обеспечении своей безопасности. Вместе с тем, Венгрия ищет возможности для развития прагматичного партнерства на всех других направлениях, включая Россию. 


\section{Формирование правительства}

После утверждения результатов выборов президент Венгрии Янош Адер поручил лидеру победившей коалиции Виктору Орбану сформировать правительство. По счету, это уже четвертый кабинет, с которым собирается работать создатель партии ФИДЕС. Его состав стал известен в конце апреля. Из тринадцати назначенных министров семеро получили столь высокие назначения впервые. Так, министерство обороны возглавил профессиональный военный; во главе министерства людских ресурсов появился врач-онколог, руководитель одной из крупнейших клиник; сменилось руководство аграрного ведомства и министерства по делам собственности. Впервые появилось министерство по делам Пакша - что указывает на грандиозность осуществляемого вместе с Россией проекта, а также министерство по делам инноваций и технологий. В целом можно говорить о тенденции к приводу к управлению государством людей, наиболее отвечающих современным тенденциям развития и досконально знающих поручаемое им дело. Аналитики увидели в новых назначениях намерение правительства и далее концентрироваться на исполнении в первую очередь задач, связанных с укреплением национального суверенитета страны.

\section{Оппозиция}

Проигравшие выборы наиболее крупные партии - социалисты и либералы с первой минуты после объявления результатов выборов обещали лидеру ФИДЕС нелегкую жизнь. В конце апреля - начале мая прошло несколько достаточно крупных митингов в Будапеште и ряде городов страны. На проведение этих акций давалось разрешение властей, которые согласились допустить несогласных и на площадь перед парламентом страны, ставшей с середины первой декады 2000-х уже традиционным местом изъявления недовольства буквально «под окнами у власти».

Кроме того, руководство Верховного суда (Kúria)- с которым у Виктора Орбана всегда были напряженные отношения - смогло аннулировать один депутатский мандат победившей коалиции, усмотрев нарушение условий голосования в том, что зарубежные венгры не всегда отправляли бюллетени в специально предназначенных конвертах. Так оппозиция приветствовала признание недействительными бюллетени, поступившие в избирательную комиссию в обычных почтовых конвертах. Однако, лишение одного мандата не повлияло на конституционное большинство в парламенте, которое осталось у ФИДЕС/ПНХД.

По всему видно, что оппозиция малочисленна и разрознена, сосредоточена преимущественно в столице и представлена в основном студенчеством и интеллигентами, служащими мультинациональных фирм. Главному же оппозиционеру - бывшему лидеру социаллиберального кабинета Ференцу Дюрчааню народ не доверяет уже давно. Другие заявившие о потенциальном лидерстве представители манифестантов не могут найти общей почвы для более массовых и консолидированных выступлений, не имеют программы действий кроме свержения существующего кабинета, не имеют за своими плечами привлекательного опыта управления, не обладают необходимой для политического лидерства харизмой и авторите- 
том. Однако все это не означает, что ФИДЕС ждет безоблачное правление и он может успокоиться на достигнутом. Сам Виктор Орбан появился на гребне венгерской политики в конце 1980-х годов весьма неожиданно, но решительно оседлал поднявшуюся политическую волну. Судя по новым программным установкам кабинета, руководство страны это понимает и также обещает проявить решительность.

\section{References}

Nemzeti választási iroda. URL: www.valasztas.hu

Itt a nyegyedik Orban kormány / Index.27.04,2018. URL: www.index.hu

Magyar hirláp. URL: magyarhirlap.hu

Kormanyzat. www.kormany.hu

\section{Hungarian parliamentary elections 2018}

Author. Lyubov Shishelina - Doctor of Sciences (History), Head of Department for Central and Eastern European Studies, Institute of Europe RAS. Address: 11-3 Mokhovaya Street, Moscow, 125009, Russia. E-mail: 1.shishelina@gmail.com

Abstract. Hungarian parliamentary elections in 2018 for the fourth time in the new history of the country brought victory to FIDESZ. At the same time, the current election campaign ended with an unprecedented failure of the social-liberal opposition, notwithstanding the active support of the official Brussels. Resignation of the founder and permanent leader of the right-wing party Jobbik became another surprise of the recent campaign, despite his party's best result in the modern history (for the first time, it bypassed its political rivals and, at the same time, its opposition allies the Hungarian socialists). However, despite another convincing victory, FIDESZ's new cabinet will not have an easy time. It will have to rule against the background of the opposition attempts to unite, as well as in constant confrontation with the official Brussels.

Keywords: parliamentary elections, Hungary, party-political struggle, FIDESZ, opposition.

DOI: http://dx.doi.org/10.15211/vestnikieran2201811 